\title{
Marginal Benefits of Grazing and Agricultu- ral Practices on a Mexican Ejido
}

DONALD A. JAMESON, J. ROBERTO ARMIJO-T., J. GALO MEDINA-T., AND ROBERTO NAVA-C.

\section{Abstract}

The ejidos, or communal farms, of northeastern Mexico traditionally produce cattle, goats, corn, and beans. In addition, several plant species are gathered for sale as food, fiber, or other uses. The present governmental policy is to provide price supports for the gathered plants as an incentive for families to remain on the ejidos. An alternative to this program is a program of grazing land improvements to provide increased forage for cattle and goats. On the Ejido Noria de Guadalupe in the state of Zacatecas, analysis of the marginal contribution of increments of labor clearly shows that improvement of grazing would be more effective in attracting families to the ejidos than the present practice of price supports but would result in some challenging changes in social organization.

\section{Resumen}

Los ejidos o predios comunales del norte de Mexico se caracterizan por ser productores de ganado vacuno y caprino, y en menor escala, productores de maiz y frijol. Como una actividad adicional se realizan colectas de ciertas especies nativas de las cuales se obtiene fibra, hule, productos quimicos y alimento para humanos. La politica actual del gobierno consiste en subsidiar estas actividades para proporcionar empleo y fortalecer el arraigo al ejido. Una alternativa al programa actual consiste en incrementar la produccion de forraje, mediante una serie de mejoras en el manejo total del ejido. En el caso especifico del ejido Noria de Guadalupe, Zac., el analisis demuestra que los margenes de contribucion, debido $a$ un incremento en la fuerza de trabajo, son mayores para las actividades de pastoreo bajo las condiciones propuestas que la practica de subsidio vigente en la actualidad. Sin embargo, esta nueva propuesta demanda desafientes combios en la organizacion productiva del ejido para que sea congruente con las estrategias de manejo propuestas.

The ejidos of Mexico are communal farms established as a result of agrarian reforms; the dewellers of ejidos are known as ejidatarios. Some ejidatarios, particularly those living at the higher elevations and on lands with higher prescription, enjoy a fairly high standard of living; but the ejidatarios living at lower elevations generally are in a state of severe poverty. A change in methods of management seems to be in order for the more impoverished ejidos, and several new technologies have been suggested as a result of field experiments and observations of management in more developed areas. Since the ejidatarios do not have managerial experience with these new technologies, several governmental programs have attempted to provide managerial guidance toward more profitable agricultural practices.

The problem, common in land management planning, is to select management actions which best utilize a set of scarce resources to maximize a goal such as net revenue or another index of social welfare. One widely used mathematical approach to solving this

\footnotetext{
Authors are professor, Department of Range Science, Colorado State University; group leader, Manejo Integral de Recursos Renovables, Analisis de Sistemas en Zonas Aridas, Saltillo, Coahuila, Mexico; and professors, Department of Natural Resources, Antonio Narro University (UAAAN), Saltillo, Coshuila, Mexico. Financial support was provided by Analisis de Sistemas en Zonas Aridas.

Manuscript received September 26, 1983.
}

problem is linear programming. Although linear programming is commonly thought of as a suitable way to calculate the "optimal" plan for a single firm or agency, the basic technique can also be used to examine the structure of a production system when several, perhaps conflicting, individuals are collectively involved. In this instance a set of linear programming problems are solved to show appropriate management strategies with different numbers of individuals active in the production system, and to determine the marginal benefits of labor as individuals enter and leave.

\section{Study Area}

The geographical area used in this study was the Ejido Noria de Guadalupe, located about midway between Zacatecas, Zacatecas, and Saltillo, Coahuila, Mexico, adjacent to the Zacatecas-Saltillo highway. Originally founded in 1948 and expanded in 1968, the ejido covers an area of about 16,671 ha. Vegetation consists of 5 primary types: halophyte shrub (Atriplex canescens and Suaeda mexicana), 1,504 ha; halophyte grassland (Sporobolus airoides and Hilaria mutica), $273 \mathrm{ha}$; Larrea-Flourensia (Larrea tridentata and Flourensia cernua), 8,395 ha; Yucca-Opuntia (Yucca filifera and Opuntia spp.), $691 \mathrm{ha}$; and Agave-Parthenium (Agave lecheguilla and Parthenium argentatum), 5,473 ha. About 335 ha are used for growing corn and beans; the rest of the area is grazed by cattle and goats.

The most productive lands for cattle grazing are the 2 halophyte communities, and to a lesser degree the Larrea-Flourensia type. The Yucca-Opuntia and Agave-Parthenium types are primarily grazed by goats. Goats are also grazed in the Larrea-Flourensia type.

In addition to cattle and goat grazing, several of the native plants are gathered for various products. These include (a) guayule (Parthenium argentatum) for rubber production, (b) agave for fiber, (c) yucca for fiber and seeds, (d) fruits (tuna) and young pads (nopalitos) of Opuntia spp. for human food, and (e) mature pads (pencas) of Opuntia spp. for livestock feed.

Approximately 50 families live on the ejido. The word "ejido" implies a communal land area, but there is considerable economic and social distinction among the resident families. A few of the most affluent families (caciques) raise cattle on the halophyte shrub and halophyte grassland and effectively exclude others from using these areas. A few additional families have cows for milk production but primarily raise goats. Most families have a few goats for milk but primarily raise corn and beans and gather the native plants for cash crops. Families of the lowest income levels may have only a few chickens and utilize only the poorer lands. Current governmental policy is designed to provide price supports for fiber and food gathering in order to encourage individuals of the lowest income levels to remain on the ejido rather than to migrate to the cities.

\section{Methods}

The analytical formulation used in this study was the standard linear programming structure: 
Maximize cx

Subject to $\mathbf{A x} \leq \mathbf{b}$

where $\mathbf{c}$ is a vector of costs and revenues, $\mathbf{x}$ a vector of production possibilities, $\mathbf{A}$ a matrix of production coefficients, and $\mathbf{b}$ a vector of constraints. For this study the formulation is further detailed as described by D'Aquino (1974):

$$
\begin{aligned}
& \text { Maximize } c_{2} x_{2}-c_{1} x_{1} \\
& \text { Subject to: } A_{1} x_{1}=b_{1} \\
& A_{2} x_{1}-A_{3} x_{2} \geq 0 \\
& A_{1} x_{2} \geq b_{3}
\end{aligned}
$$

where $c_{1}$ is a vector of costs of land treatments (pesos), $x_{2}$ is a vector of revenue from product sales (pesos), $x_{1}$ is a vector of land treatments (ha), $x_{2}$ is a vector of revenue producing activities (in $\mathrm{kg}$ or other units), $b_{1}$ is a vector of land areas (ha) or other resource constraints, $3_{\mathrm{g}}$ is a vector of desired outputs (in kg or other units), $A_{1}$ is a submatrix with elements of 1 if a land treatment is used on a land area and 0 otherwise, $\mathbf{A}_{2}$ is a submatrix of production coefficients in $\mathrm{kg}$ / ha or animal unit years (AUY)/ ha resulting from land treatments, $A_{3}$ a submatrix of coefficients expressing use of intermediate outputs by revenue producing activities, and $A_{4}$ a submatrix of 1 's and 0 's linking the revenue producing activities to desired output levels or goals. The function to be maximized, variable benefits less variable costs, is defined as the contribution margin in accounting literature and as gross margin in farm management literature; the increase in contribution margin per unit of labor is defined as the marginal contribution of labor. Decision variables (the $\mathbf{x}$ vector) applied to the land are designated as "prescriptions," and each prescription may contain one more more management practices.

Several management prescriptions (i.e., one or more practices on a land area) detailing various degrees of production technology were described for each vegetation type. These prescriptions included such practices as rest-rotation grazing, shrub control, and combinations of grazing systems and shrub control. The practices considered for each type also included "do nothing new" (i.e., the current practices) and "do nothing" (i.e., discontinue all active use of the land); the latter category was included as a device to account for all land areas. A water-use constraint was also included, but this constraint had little impact on the model results since water use and cropland are already carefully balanced.

For each of the 5 vegetation types and the cropland, a series of 3 to 10 existing and potential management practices were described, and production coefficients such as animal unit year (AUY) of grazing animals per ha and $\mathrm{kg}$ of fiber per ha developed for each. The coefficients and practices were based on previous experimental work at the Campo Experimental de Noria de Guadalupe. Detailed descriptions of the coefficients are given in Medina (1980) and Armijo (1981). The coefficients in these previous reports are identical, but the model formulations were different.

A second model was derived from the first which basically included the "do nothing new" and "do nothing" practices. The purpose of this model was to allow analysis of marginal benefits with only the current management strategies available. Higher, possibly destructive, rates of grazing by cattle were allowed in this model to more accurately reflect the current situation; i.e., the coefficients for cattle grazing on the halophyte types were set at 0.37 AUY/ha with the "do nothing new" practice. These coefficients were necessary so that the calculated number of cattle grazing the halophyte land type would correspond to the current number of animals. This latter model will be called the "current technology" model, and the model presented earlier by Medina will be called the "new technology" model.

The original model developed by Medina included gathering young pads of Opuntia spp. or "nopalitos." This activity, although seasonal, has a sufficiently high rate of return in the free market so that it is profitable as a separate enterprise. With the large amount of Opuntia available, the resultant nopalito gathering completely dominated all linear programming solutions. Because nopalito gathering obscured the determination of the economic value of other activities, it was necessary to either numerically constrain the nopalito harvest or to delete it from the model. Questions of regional supply and demand are important for the nopalito harvest but are not investigated here. The other gathered products are of sufficiently low profitability that the possibility of regional oversupply does not seem to be a relevant question from the viewpoint of a single ejido.

The "current technology" and "new technology" models were analyzed for optimal strategies using parametric or sensitivity analysis of labor ranging from 1,000 to 20,000 days of labor with increments of 1,000 days, and from 20,000 to 130,000 days or labor using increments of 10,000 days. Production of various outputs which could result from these optimal strategies are shown in Table 1 for the current technology and Table 2 for the new technology. Marginal contributions of days of labor are also shown in Figure 1.

In analyses such as linear programming it is to be expected that the most profitable strategies with the lowest labor input would be selected and that less and less profitable practices would be implemented as labor increases. When labor is not a constraint, as is effectively the case when 130,000 days of labor are available, linear programming will select that combination of practices which maximizes the contribution margin even though the contribution of the last increment of labor may be very small.

In linear programming the solution process identifies a series of optimal corner points in a solution space. The identification of changes in optimal points as some constraint is eased is generally called sensitivity analysis. Between the optimal points lie "plateaus" wherein one practice can be exchanged for another without loss of contribution margin. Although this may at first seem to be a fault in the formulation, in fact, it is a realistic expression of the actual situation. As more profitable land areas are fully utilized, production naturally shifts to the next category of land. Once production begins on a land type, a sizeable area may become available which will require several increments of labor input to fully utilize the land type. As rather broad plateaus of "optimal" operational strategies result from these analyses, the range of days of labor required for these plateaus is of sufficient magnitude to suggest that social groups which specialize in the activities of a production plateau could be identified.

\section{Results}

\section{Current Technology}

Observations made since about 1972 at the Ejidor Norio de Guadalupe indicate that preferred production activities at Noria de Guadalupe are, in order, (1) cattle raising, (2) goat raising, (3) corn and bean farming, (4) agave fiber and guayule gathering, and (5) yucca fiber and yucca seed gathering. If the formulation of the "current technology" model is reasonable, the preferred activities should occur in the same sequence in an economic model.

At the currently estimated labor force of 27,375 days of labor per year, production activities for the "current technology" model include cattle grazing, goat grazing, bean growing, and agave fiber and guayule gathering; these activities also currently occur at the ejido. In addition, the order of economic activities for the current technology is, as shown in Table 1, the same as the socially preferred order. Labor inputs from 0 to 1,000 days gave an average yield of $\$ 7,458$ (pesos $^{1}$ ) per days, an obviously profitable and same order of social acceptance because of the need to have corn, increment was cattle grazing. Additions of labor from 1,000 to 5,000 days resulted primarily in goat grazing with a marginal contribution of labor of $\$ 991$ per day. From 6,000 to 11,000 days

In this paper the $\$$ symbol, in keeping with long-standing Mexican practice, will be In this paper the \$ symbol, in keeping with long-standing Mexican practice, will be about 1776 . The peso value ranged from 0.022 to 0.007 US dollars during the course of the study. 
the new productive efforts were in growing beans with a marginal contribution of $\$ 389$ per day. (Corn growing is probably of the same order of social acceptance because of the need to have corn, but appeared in the solution only if forced because it is less profitable than bean growing and competes for the same type of land.) From 12,000 through 50,000 days the new activities included agave and guayule gathering, with small increases in goat raising, for a marginal contribution corresponding closely to the $\$ 220$ per day, the current standard minimum labor wage in Mexico. At 70,000 days and beyond, the marginal contribution dropped to $\$ 177$ and less per day. The total contribution margin at 27,375 days of labor was about $\$ 17,500.000$.

\section{New Technology}

The "new technologies" selected by the linear programming model involved primarily shrub control and rest-rotation grazing. The results from the new technology model showed that cattle grazing and goat grazing would still be the most preferred activities but with major increases in cattle production. Management activities selected in the linear programming solutions are described in the next section. Details of both selected and nonselected activities can be found in Medina (1980) and Armijo (1981).

For the first 1,000 days of labor, the new technology would yield only $\$ 3,734$ per day as contrasted to $\$ 7,458$ for the current technology results because a "destructive" grazing rate was not allowed in the new technology model. The average for the first 3,000 days of labor with the current technology was $\$ 3,347$ compared to $\$ 3,147$ for the current technology with the same labor. From 6,000 through 9,000 days labor, however, the new technology would result in about 1,500 cattle compared to 615 cattle, and 0 goats compared to 2,351 goats with the current technology. With a labor force of 30,000 days, which is approximately the current labor force, the goat numbers of the two technologies would be essen- tially the same at 2,750 goats while cattle numbers would be 2,247 compared to the present 615 .

The new technology model included gathering activities, which are key to range improvement practices, because properly designed gathering allows increased growth of desired forage species and properly designed grazing can contribute to the growth of species to be gathered. Thus, gathering would occur with a marginal contribution of labor in the range of $\$ 400$ to $\$ 600$ per day as contrasted to $\$ 227$ per day with the current technology model. This gives rise to one possible scenario which could result from adoption of the new technology: some gathering would be done with the existing labor force. However, because of the integration of gathering and grazing the marginal contribution per labor day for the integrated practices would be about 3 times that of current practices of gathering alone. With a labor force of 27,375 days, the contribution margin with the new technology would be $\$ 27,500,000$ compared to $\$ 17,500,000$ with the current technology.

One of the objectives of improved ejido management is to attract, or at least to hold, individuals to the ejido, thus inmigration rather than increased income to existing residents would be considered a desirable effect. This assumption gives rise to a second scenario: if the improved profitability of the new technology resulted in an in-migration to the ejido until the marginal contribution reached the current level, the resultant labor force would be 120,000 man days, or about 4 times the current labor force.

\section{Land Management Implications}

Since the optimal combination of technologies depends on the assumptions made about labor supply, selecting a sequence of technologies to initiate with different amounts of labor becomes an important question. Both the social acceptability of the technolo-

Table 1. Outputs and marginal contribution of labor per day for the "current technology" alternative.

\begin{tabular}{|c|c|c|c|c|c|c|c|c|}
\hline $\begin{array}{l}\text { Labor } \\
\text { (days) }\end{array}$ & $\begin{array}{l}\text { Cattle } \\
\text { (head) }\end{array}$ & $\begin{array}{l}\text { Goats } \\
\text { (head) }\end{array}$ & $\begin{array}{c}\text { Beans } \\
(\mathrm{kg})\end{array}$ & $\begin{array}{l}\text { Agave fiber } \\
\text { (kg) }\end{array}$ & $\begin{array}{c}\text { Rubber } \\
\text { (kg) }\end{array}$ & $\begin{array}{l}\text { Yucca fiber } \\
(\mathrm{kg})\end{array}$ & $\begin{array}{l}\text { Yucca seeds } \\
(\mathbf{k g})\end{array}$ & $\begin{array}{c}\text { Marginal contribution } \\
\text { (Pesos) }\end{array}$ \\
\hline 1000 & 737 & 272 & 0 & 0 & 0 & 0 & 0 & 7458 \\
\hline 2000 & 707 & 789 & 0 & 0 & 0 & 0 & 0 & 991 \\
\hline 3000 & 677 & 1306 & 0 & 0 & 0 & 0 & 0 & 991 \\
\hline 4000 & 646 & 1822 & 0 & 0 & 0 & 0 & 0 & 991 \\
\hline 5000 & 616 & 2339 & 0 & 0 & 0 & 0 & 0 & 991 \\
\hline 6000 & 615 & 2351 & 27140 & 0 & 0 & 0 & 0 & 403 \\
\hline 7000 & 615 & 2351 & 54920 & 0 & 0 & 0 & 0 & 389 \\
\hline 8000 & 615 & 2351 & 82699 & 0 & 0 & 0 & 0 & 389 \\
\hline 9000 & 615 & 2351 & 110478 & 0 & 0 & 0 & 0 & 389 \\
\hline 10000 & 615 & 2351 & 138258 & 0 & 0 & 0 & 0 & 389 \\
\hline 11000 & 615 & 2351 & 166037 & 0 & 0 & 0 & 0 & 389 \\
\hline 12000 & 615 & 2371 & 167500 & 3679 & 510 & 0 & 0 & 236 \\
\hline 13000 & 615 & 2392 & 167500 & 7562 & 1048 & 0 & 0 & 227 \\
\hline 14000 & 615 & 2413 & 167500 & 11446 & 1586 & 0 & 0 & 227 \\
\hline 15000 & 615 & 2434 & 167500 & 15239 & 2124 & 0 & 0 & 227 \\
\hline 16000 & 615 & 2455 & 167500 & 19213 & 2662 & 0 & 0 & 227 \\
\hline 17000 & 615 & 2476 & 167500 & 23096 & 3200 & 0 & 0 & 227 \\
\hline 18000 & 615 & 2497 & 167500 & 26980 & 3738 & 0 & 0 & 227 \\
\hline 19000 & 615 & 2518 & 167500 & 30863 & 4276 & 0 & 0 & 227 \\
\hline 20000 & 615 & 2539 & 167500 & 34747 & 4814 & 0 & 0 & 227 \\
\hline 30000 & 615 & 2750 & 167500 & 73582 & 10195 & 0 & 0 & 227 \\
\hline 40000 & 615 & 2960 & 167500 & 112417 & 15576 & 0 & 0 & 227 \\
\hline 50000 & 615 & 3171 & 167500 & 151252 & 20957 & 0 & 0 & 227 \\
\hline 60000 & 615 & 3303 & 167500 & 197268 & $2434 I$ & 0 & 0 & 216 \\
\hline 70000 & 615 & 3152 & 167500 & 269369 & 20476 & 0 & 0 & 177 \\
\hline 80000 & 615 & 3001 & 167500 & 341469 & 16610 & 0 & 0 & 177 \\
\hline 90000 & 615 & 2849 & 167500 & 413570 & 12745 & 0 & 0 & 177 \\
\hline 100000 & 615 & 2698 & 167500 & 485671 & 8879 & 0 & 0 & 177 \\
\hline 110000 & 615 & 2547 & 167500 & 557772 & 5014 & 0 & 0 & 177 \\
\hline 120000 & 615 & 2396 & 167500 & 629873 & 1148 & 0 & 0 & 177 \\
\hline 130000 & 615 & 2441 & 167500 & 651287 & 0 & 11747 & 173441 & 128 \\
\hline
\end{tabular}


gies and their ecological impacts must be considered.

For the current technology scenario the optimal sequence of activities is (1) graze the halophyte communities with cattle, (2) graze the Larrea-Flourensia community with goats, (3) raise beans and corn on the croplands, (4) gather agave and guayule from the Agave-Parthenium type, and (5) gather yucca fiber and seeds from the Yucca-Opuntia type.

For the new technology scenario the optimal sequence of activities is somewhat more complex. In instituting a new technology it is important to avoid taking irreversible steps at an early stage which would prevent adopting a more productive technique at a later stage. Fortunately, this does not seem to be a problem in this example as long as the management uses a labor force of less than 70,000 days.

The most efficient (i.e., the greatest monetary increase per unit of monetary input) of the new technologies would be to initiate a rest-rotation system in the Larrea-Flourensia type. However, since total gains possible in animal numbers with this practice are low, it would probably create less interest than more intensive practices. The second most profitable practice is improvement of the 2 halophyte communities. Unpalatable shrubs should be removed manually to save the more palatable shrubs, thus fostering the increase of those shrubs and grasses. To maintain the number of shrubs not preferred by cattle at a low level, goat grazing should be instituted after the initial shrub control action. Because extensive use of fourwing saltbush or chamizo (Atriplex canescens) reputedly reduces goat milk production, it should be easy to convince goat herders to avoid excessive grazing on this species and to concentrate on other shrub species. This may cause some social problems as goats and cattle traditionally are not grazed in the same areas. However, a rotation system could be initiated so that goats and cattle do not graze an area at the same time; the rotation system itself would also benefit cattle grazing directly (Reardon and Merrill 1976). Shrub control without subsequent rotation grazing and use of goats would result in a more rapid return of the unpalatable shrubs. Shrub control followed only by a rotation grazing system with cattle is also a useful practice but would probably be more expensive to maintain due to brush revinvasion. Even with a conservative stocking rate, all of the present commercial cattle could be grazed on the improved halophyte communities.

Except for possible objections to grazing cattle with goats, using goats to reduce shrub reinvasion should be a highly desirable practice. If the new grazing on the halophyte vegetation type capacity were limited to the present users of these lands, there should be good social support. However, prior to shrub control there should be a firm agreement on the institution of rotation grazing systems between the livestock owners and the government agency providing support.

The next most productive activity is to improve grazing via shrub control in the Larrea-Flourensia vegetation type. As noted above, practices such as rest-rotation grazing could cause such an improvement. This would probably be acceptable for herded goats but, because of capital costs in fencing, would require some additional incentive for cattle owners. A shrub control program followed by rest-rotation grazing would allow even further increases in grazing for cattle. In this vegetation type the shrub control practices can be mechanical (such as railing) since there is no need to preserve palatable shrubs. As in the case of the halophyte land types, livestock owners and agency personnel should make firm agreements on grazing practices before the shrub clearing is begun. With a well-designed grazing system this type could support an additional 1,200 head of cattle. The dominant shrub in this type, Larrea tridentata, has little useful value at present, but development of commercial uses of this species would at least partially offset the cost of shrub control.

The first 2 sets of treatments outlined above promise to be so

Table 2. Outputs and marginal contribution of labor per day for the "new technology" alternative.

\begin{tabular}{|c|c|c|c|c|c|c|c|c|}
\hline $\begin{array}{l}\text { Labor } \\
\text { (days) }\end{array}$ & $\begin{array}{l}\text { Cattle } \\
\text { (head) }\end{array}$ & $\begin{array}{l}\text { Goats } \\
\text { (head) }\end{array}$ & $\begin{array}{l}\text { Beans } \\
(\mathrm{kg})\end{array}$ & $\begin{array}{l}\text { Agave fiber } \\
\text { (kg) }\end{array}$ & $\begin{array}{l}\text { Rubber } \\
\text { (kg) }\end{array}$ & $\begin{array}{l}\text { Yucca fiber } \\
\text { (kg) }\end{array}$ & $\begin{array}{l}\text { Yucca seeds } \\
(\mathrm{kg})\end{array}$ & $\begin{array}{c}\text { Marginal contribution } \\
\text { (Pesos) }\end{array}$ \\
\hline 1000 & 405 & 0 & 0 & 0 & 0 & 0 & 0 & 3734 \\
\hline 2000 & 845 & 0 & 0 & 0 & 0 & 0 & 0 & 4051 \\
\hline 3000 & 1092 & 0 & 0 & 0 & 0 & 0 & 0 & 2256 \\
\hline 4000 & 1213 & 0 & 0 & 0 & 0 & 0 & 0 & 1083 \\
\hline 5000 & 1313 & 0 & 0 & 0 & 0 & 0 & 0 & 846 \\
\hline 6000 & 1404 & 0 & 0 & 0 & 0 & 0 & 0 & 746 \\
\hline 7000 & 1495 & 0 & 0 & 0 & 0 & 0 & 0 & 746 \\
\hline 8000 & 1586 & 0 & 0 & 0 & 0 & 0 & 0 & 746 \\
\hline 9000 & 1677 & 0 & 0 & 0 & 0 & 0 & 0 & 746 \\
\hline 10000 & 1748 & 48 & 0 & 0 & 0 & 0 & 0 & 736 \\
\hline 11000 & 1773 & 205 & 0 & 0 & 0 & 0 & 0 & 712 \\
\hline 12000 & 1798 & 361 & 0 & 0 & 0 & 0 & 0 & 712 \\
\hline 13000 & 1823 & 518 & 0 & 0 & 0 & 0 & 0 & 712 \\
\hline 14000 & 1849 & 675 & 0 & 0 & 0 & 0 & 0 & 712 \\
\hline 15000 & 1874 & 832 & 0 & 0 & 0 & 0 & 0 & 712 \\
\hline 16000 & 1899 & 989 & 0 & 0 & 0 & 0 & 0 & 712 \\
\hline 17000 & 1924 & 1145 & 0 & 0 & 0 & 0 & 0 & 712 \\
\hline 18000 & 1949 & 1281 & 0 & 0 & 848 & 0 & 0 & 681 \\
\hline 19000 & 1974 & 1406 & 0 & 0 & 2143 & 0 & 0 & 665 \\
\hline 20000 & 1999 & 1531 & 0 & 0 & 3438 & 0 & 0 & 665 \\
\hline 30000 & 2247 & 2781 & 0 & 0 & 16393 & 0 & 0 & 665 \\
\hline 40000 & 2496 & 4031 & 0 & 0 & 29348 & 0 & 0 & 665 \\
\hline 50000 & 2564 & 5258 & 0 & 0 & 31196 & 9536 & 138524 & 478 \\
\hline 60000 & 2509 & 5867 & 167500 & 0 & 31196 & 13129 & 190716 & 389 \\
\hline 70000 & 2007 & 8282 & 167500 & 0 & 31196 & 13129 & 190716 & 303 \\
\hline 80000 & 1787 & 9893 & 167500 & 0 & 31196 & 13129 & 190716 & 267 \\
\hline 90000 & 1572 & 11487 & 167500 & 0 & 31196 & 13129 & 190716 & 265 \\
\hline 100000 & 1357 & 13080 & 167500 & 0 & 31196 & 13129 & 190716 & 265 \\
\hline 110000 & 1143 & 14674 & 167500 & 0 & 31196 & 13129 & 190716 & 265 \\
\hline 120000 & 994 & 15730 & 167500 & 20662 & 30206 & 13129 & 190716 & 237 \\
\hline 130000 & 998 & 15635 & 167500 & 85690 & 27092 & 13129 & 190716 & 178 \\
\hline
\end{tabular}




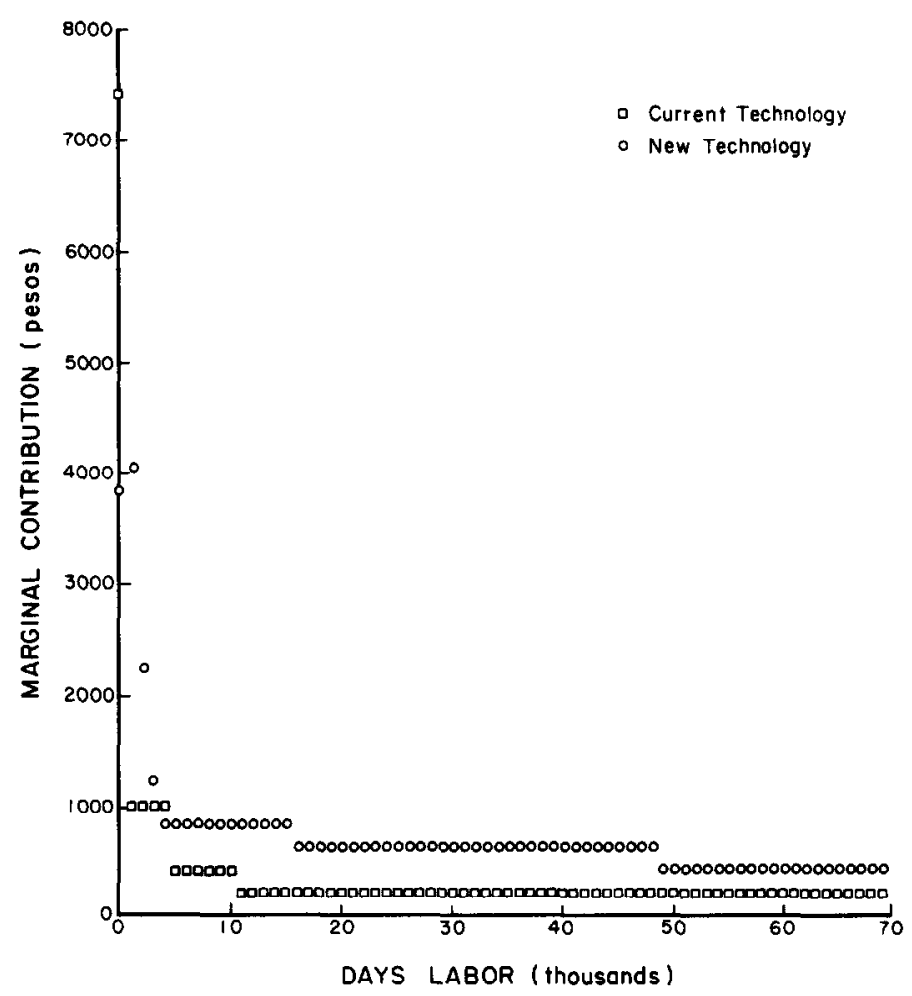

Fig. 1. Marginal contribution (vertical axis) related to days labor (horizontal axis).

productive that traditional corn and bean raising would be even less profitable by comparison than they are at present. However, if the introduction of improved production practices allowed corn yields to be raised from the currently estimated $250 \mathrm{~kg} / \mathrm{ha}$ to about $1,250 \mathrm{~kg} / \mathrm{ha}$ and bean yields from $500 \mathrm{~kg} / \mathrm{ha}$ to $750 \mathrm{~kg} / \mathrm{ha}$, these crops would be competitive with other activities of the ejido even with improved technologies for livestock production. Historically, introduction of new corn and bean raising technology has met with little success.

Improvements on the Agave-Parthenium and Yucca-Opuntia sites will be more subtle and less profitable than on the other vegetation types. Gathering of agave, guayule, yucca, and nopalitos should continue to be encouraged. However, research should be done to identify sites where improved grazing capacity will result from the gathering efforts. Thus, economic benefits could accrue from both the sale of the plant products and improved grazing. Seasonally selected goat grazing should be promoted in these areas to reduce competition and promote growth of the Yucca, Opuntia, Agave, and Parthenium plants.

On the Agave-Parthenium type, Parthenium argentium is very susceptible to competition from other plants. In a preliminary study Gonzales (1982) found that goats do not readily browse Parthenium argentium but do browse other species of Parthenium. Thus, a program of agave gathering and goat grazing could be designed to promote growth of guayule.

Although grazing by either goats or cattle is marginal on the Yucca-Opuntia type, no "normal" grazing is probably best on this type (essentially the "do nothing" prescription). Yucca and nopalito gathering could still be an important activity on this type but would require no particular management planning.

Although the most intensive goat browsing would be on the halophyte shrub with 1,200 goats, an additional 2,000 goats could be used on the remainder of the area, especially the AgaveParthenium type which is currently mostly unused. Thus, the new technology would not require a reduction of goat numbers but would require some changes in location. If grazing and harvesting practices were integrated, use of the new locations would be more profitable than at present. Movement of goats from their traditional grazing areas could be promoted if there were some mechanism for goat owners to share in the proceeds of integrated management.

Reseeding with species such as Bouteloua curtipendula, Eragrostis lehmanni, and Sporobolus cryptandrus was not included because of lack of data on success and yields, but reseeding obviously should be considered. Also not included in the model are site differences within the ubiquitous Larrea-Flourensia type, which could be important for specific locations of improvement practices.

Reardon and Merrill (1976) have outlined important results which should be considered in designing grazing systems where both cattle and goats are used. Once the halophyte and LarreaFlourensia types have been improved and rest-rotation grazing systems initiated, the continued success of this program will depend on observations to determine changes, if any, which are needed in animal numbers.

\section{Discussion and Conclusions}

As stated in the section on study area, the current governmental policy is to provide price supports for fiber gathering to encourage ejido dwellers to remain on the ejido. Marginal contribution analyses of current and possible future technologies on the Ejido Noria de Guadalupe suggest that improvement of basic grazing capacity will be more effective in maintaining the economic health and population size of the ejido than the current program of price supports for gathering of plant products.

To achieve the support of present influential cattle owners, who presently dominate or "own" the better grazing areas, a program of manual shrub control and improved grazing practices should be introduced on the productive halophyte shrub and grassland types. In addition, a major program of mechanical or manual shrub control should be initiated on selected sites of the LarreaFlourensia type. The resultant increased grazing capacity, mostly suitable for cattle, could be utilized by expanded herds of present cattle owners, by changes of some goat owners to cattle owners, or by new livestock owners. If new cattle owners enter the system, a training program in cattle management probably would be necessary.

Present and new owners of goats should be encouraged to use the Yucca-Opuntia and Agave-Parthenium sites as goat grazing in these areas would promote growth of plant species more suitable for gathering than for grazing. A study of site potentials in these areas would allow concentration of goat grazing and shrub control on the most productive sites.

Application of these production practices can be expected to raise the average income of the present labor force about 1.6 times. Most of the increased income would accrue to an expanded midrange economic group as production shifts to increased numbers of cattle. Alternatively, the result could be an in-migration to the ejido up to a population level of about 4 times the present numbers before the present income level of the poorer inhabitants is again reached. It is clear from the model results that improvement of the grazing capacity would be a more effective mechanism than the present program of price supports for gathering activities. However, utilization of the increased capacity would require innovations in social organization of the ejidos, such as the formation of grazing associations and capitalization for new livestock owners, which do not presently exist.

\section{Literature Cited}

Armijo-Tamez, J.R. 1981. Multiobjective design of development programs with application to the San Tiburcio Region, Zacatecas, Mexico. Ph.D. Diss., Univ. of Arizona, Tucson.

D'Aquino, S.A. 1974. A case study of optimal allocation of range resources. J. Range Manage. 27:228-233. 
Gonzales, H. 1982. Botanical composition of goat's diet in northern Zacatecas, Mexico. M.S. Thesis. Colorado State Univ., Fort Collins.

Medina-Torres, J.G. 1980. Critical elements in land use and research design in northern Mexico. Ph.D. Diss., Colorado State Univ., Fort Collins.
Reardon, P.o., and L.B. Merrill. 1976. Vegetative response under various grazing systems in the Edwards Plateau of Texas. J. Range Manage. 29:195-198. 